\title{
IPO Returns: Pre And Post Dotcom Bubble
}

Danny Kayne, Colorado College

Judith Laux, (E-mail: jlaux@ coloradocollege.edu), Colorado College

\begin{abstract}
This study inspects the relative first-day returns of tech/internet IPOs before, during, and after the 1999-2000 dotcom "bubble" to investigate whether market inefficiency and agency conflicts were resolved. Using IPOs during the 1990 to 2004 period, we discover significant reversals in underpricing of internet IPOs following the large-scale investigation of IPO valuation practices led by New York State Attorney General Elliot Spitzer.
\end{abstract}

\section{INTRODUCTION}

ur investigation of the relative pricing of internet and non-internet IPOs begins with a general look at the underpricing phenomenon. "Underpricing" occurs when issuing firms receive less than a market-based "fair" price, and early, often handpicked, buyers receive more as they later sell the initially underpriced shares. At issue is whether such mispricing represents a wealth transfer that provides evidence of principal-agent conflicts. Also at issue is whether markets are inefficient, as the last to buy experience lower than expected riskadjusted returns on their investment. The current study reviews literature related to IPO pricing and compares returns in the periods surrounding the dotcom bubble. The following section introduces the underpricing phenomenon along with general descriptive statistics and is followed by a more complete review of the literature and a short section on one of the premier players in the IPO scandal, Frank Quattrone. This is followed by data, results, and conclusions.

\section{THE UNDERPRICING PHENOMENON}

Initial public offerings attracted empirical investigation long before the dotcom bubble of the late 1990s, primarily because they represent a true test of valuation. Underwriters are charged with researching the industry and macroeconomic conditions faced by the launching firm and must offer guidance on the appropriate per share price. Confronted with the possibility of overpricing the security and having a failed offering, the temptation is to err in the other direction. Similarly, managers, who normally will hold shares for a certain lockup period, also stand to benefit from a stock price that will soar rather than settle. Studies prior to the dotcom period indicated that first-day returns had not risen above $21.1 \%$ (figure for 1995) [Reilly and Norton, 2003, p. 318] and averaged 16.4\% [Ritter, 1991, p. $3]$.

In 1999 and 2000, however, average first-day returns swelled to 69\% and 55.5\%, respectively [Reilly and Norton, 2003, p. 318], and this apparent market imbalance did not go unnoticed. An investigation into IPO allocation, pricing, and favoritism commenced, and regulatory actions ensued. ${ }^{1}$ This paper looks at post-dotcom returns for evidence that these reforms improved market efficiency. The following section offers a more detailed review of the pertinent literature.

\footnotetext{
${ }^{1}$ For a good picture of this period, including Frank Quattrone's apparent role, see the following: Smith [2003]; Elkind et al [2001]; Gasparino and Schroeder [2002]; Gasparino [2002]; Opdyke and Simon [2003]; Smith et al [2003].
} 


\section{REVIEW OF LITERATURE}

Several studies address the issue of IPO underpricing and the resultant transfer of wealth, most notably Ritter [1991], Aggarwal et al [2002], Loughran and Ritter [1995 and 2004], and Hansen [2001]. Ritter [1991] sets the tone for expected returns, providing average IPO first-day returns from 1975 to 1984. Estimated returns were found to be $16.4 \%$ on average at the end of the first trading day [Ritter, 1991,3]. Loughran and Ritter [2004] examine the effects of underpricing from the 1980s until after the dotcom bubble. According to the sample population used, during the 1980s first-day returns were a meager 7\%; from 1990 to 1998, returns more than doubled (to 15\%), and during the dotcom bubble, returns averaged 65\%. Following the dotcom bubble (2001 to 2003), average first-day returns reverted to 12\% [Loughran and Ritter, 2004, 5-12]. Aggarwal et al [2002] contrasts internet and non-internet IPOs. Their findings support two notions: 1) that underpricing and manipulative research coverage represented methods deliberately used in pricing IPOs during the 1990s and the dotcom bubble, and 2) that internet IPOs had greater underpricing. Specifically, "...the internet subsample... [171 firms with underpricing in excess of 50\%, two-thirds of which were internet-related] has significantly greater underpricing (mean of $66.2 \%$ and median of $33.3 \%$ ) than the non-internet subsample (mean of 35.2\% and median of 17.6\%)" [Aggarwal et al, 2002, 119]. Some studies address the dotcom industry specifically, including Ljungqvist and Wilhelm [2003], Johnston and Madura [2002], and Bartov, Mohanran, and Seethamraju [2002]. None, however, offers a look at all three periods to contrast internet and noninternet IPOs. Before reviewing our data and results, the following section offers a brief description of one of the major players in the IPO scandal, Frank Quattrone, and the results of the Spitzer investigation.

\section{FRANK QUATTRONE AND FALLOUT OF THE IPO INVESTIGATION}

More than any other single contributor, Frank Quattrone, an employee with Credit Suisse First Boston, is accredited with manufacturing the dotcom bubble. "Quattrone came to Silicon Valley in the early 1980s, a time when the big Wall Street firms regarded tech banking as just an interesting niche business. But Quattrone believed that the tiny, struggling companies that then made up the tech galaxy were destined to become fast-growing giants..." [Elkind et al, 2001,38]. From 1998 to 2000, Quattrone and his team underwrote 138 tech firms, more than the combined total of his competitors. Although the potential of the companies he underwrote was not always as favorable as the research that promoted the stock, Quattrone continuously made sure that optimistic coverage of the company was given to investors and that IPO shares were allocated to "friends of Frank." Regardless of his practices, Quattrone was able to hype up issuances of companies he planned to underwrite to reap high first-day returns [Elkind et al, 2001, 3443]. VA Software Corp. (previously known as VA Linux Systems) represents one example of this pricing exuberance. On December 9, 1999, Linux offered its IPO shares at \$30; suspicion of faulty pricing practices and favorable share allocation arose when first-day prices reached as high as \$299 [premium.hoovers.com, 10008]. With Quattrone dominating the tech industry, competing banks were forced to follow suit in the way they issued IPOs. Quattrone's dirty practices were becoming the industry standard [Gasparino and Schroeder, 2002, A1].

When many of the internet stocks crumbled following the first few weeks of issuance, an investigation into IPO allocation, pricing, and favoritism spearheaded by New York State Attorney General Elliot Spitzer commenced, and regulatory actions resulted. According to Smith et al, Spitzer's findings included IPO allocation favoritism, fraudulent research reports, unfair research or research not given in good faith, illegal acceptance of tainted research, and "IPO 'spinning'" [2003, C1]. Changes were mandated in the investment banking industry, and reparations (including a $\$ 1.4$ billion settlement) from the investment banks were required [Smith et al, 2003, C1, C3]. In addition, legislation included "a clear separation of stock research from investment banking, 'independent' research for investors at no cost, better disclosure of stock ratings, and the ban of IPO 'spinning'" [Zuckerman and Craig, 2003, C1, C9]. The current paper looks at post-dotcom returns for evidence that these reforms had a positive impact on market efficiency. If investment banks are conforming, agency relationships should improve, with issuing firms receiving a fairer price and markets more efficiently equating risk and return.

\section{DATA AND RESULTS}

In defining internet stock classifications (listed on the following page), we relied on a system of classification November 2004, we turned to Hoovers.com's IPO Central Website for IPO offer dates, offer prices, and first-day 
used. in Marshall et al [2004, p. 107] and SIC codes that define internet related companies. By using these two sources as sample standards, our population is synchronized with previous studies. For internet IPOs from January 1998 to closing prices. SIC code verification was found at www.osha.gov. Results from Loughran and Ritter [2004] and Johnston and Madura [2002] were also used

\begin{tabular}{|c|c|c|}
\hline Internet Classification & \begin{tabular}{|l|} 
Description of the Classification \\
\end{tabular} & Example \\
\hline Advertising & $\begin{array}{l}\text { Providing advertisement services on the Web or do } \\
\text { direct marketing }\end{array}$ & Doubleclick, Inc. \\
\hline Consulting and Designers & $\begin{array}{l}\text { Develop and install web technologies and offer Web } \\
\text { design services }\end{array}$ & MarchFIRST, Inc. \\
\hline Content and Communities & $\begin{array}{l}\text { Online communities that are formed to support } \\
\text { groups within common interests }\end{array}$ & Go2net, Inc. \\
\hline E-Commerce Enablers & Provide software for e-commerce & Ariba, Inc. \\
\hline E-Tailors & Sell to consumers online & Amazon.com, Inc. \\
\hline Financial Services & $\begin{array}{l}\text { Provide online financial services such as banking } \\
\text { and stockbrokerages }\end{array}$ & NetBank, Inc. \\
\hline ISP/Access & Provide Internet services or access & EarthLink, Inc. \\
\hline Internet Services & $\begin{array}{l}\text { Provide services such as website hosting or e-mail } \\
\text { management }\end{array}$ & Versign, Inc. \\
\hline Performance Software & $\begin{array}{l}\text { Provide software such as operating systems or } \\
\text { software for working with multimedia content on the } \\
\text { Web }\end{array}$ & Tibco Software, Inc. \\
\hline Search and Portal & $\begin{array}{l}\text { Internet Search Engines provide help to users in } \\
\text { finding information on the web. Portals provide an } \\
\text { entry to the web, often including a search engine and } \\
\text { navigation aid. }\end{array}$ & Yahoo, Inc. \\
\hline Security & $\begin{array}{l}\text { Create and sell software for Internet-oriented } \\
\text { software such as firewalls and encryption }\end{array}$ & $\begin{array}{l}\text { Check Pt Software Technology } \\
\text { LTD }\end{array}$ \\
\hline Speed and Bandwidth & $\begin{array}{l}\text { Provide services that improve the performance of } \\
\text { using the Internet }\end{array}$ & Cisco Systems, Inc. \\
\hline
\end{tabular}

SOURCE: Beverly B. Marshall, Clarie E. Crutchley, and Diane Lending, "Early Internet IPOs Versus

Subsequent Entrants," Journal of Economics and Finance 28, No. 1 (Spring 2004): 107

Table 1 on the following page shows the number of firms issuing IPOs for the three periods-pre-dotcom (1990 to 1998), dotcom (1999 to 2000), and post dotcom (2001 to 2004). These are categorized as internet related or non-internet related. By comparing both types of IPOs, first-day returns can be better understood. The numbers indicate that the pre-dotcom period was characterized by fewer dotcom IPOs (1081) than non-internet IPOs (2315), while the dotcom bubble showed a significantly different picture, with 585 internet-related IPOs in a two-year period versus 218 non-internet IPOs. The period following the bubble evidenced a significant reversal ( 86 dotcoms, 276 non-internet IPOs). Even more striking, however, are the relative yields during the three periods. For internet related IPOs, the average initial return experienced before the dotcom bubble was $22.2 \%$, while non-internet IPOs averaged a yield of $11.3 \%$. During the bubble, however, internet IPOs averaged a whopping $80.6 \%$, with non-internets averaging a relatively meager $23.1 \%$. Following the dotcom bubble, internets averaged yields of $11.4 \%$, while non-internets averaged $9.12 \%$. 
Table 1: Number of IPOs and Average Returns: Before, During, and After the Dotcom Bubble

\begin{tabular}{|l|l|l|}
\hline & \multicolumn{1}{|c|}{ Internet } & \multicolumn{1}{c|}{ Non-Internet } \\
\hline & & \multicolumn{1}{|c|}{} \\
\hline $1990-1998$ period & $\mathrm{N}=1081$ & $\mathrm{~N}=2315$ \\
\hline & Return $=22.2 \%$ & Return $=11.3 \%$ \\
\hline $1999-2000$ period & $\mathrm{N}=585$ & $\mathrm{~N}=218$ \\
\hline & Return $=80.6 \%$ & Return $=23.1 \%$ \\
\hline $2001-2004$ period & & $\mathrm{N}=276$ \\
\hline & $\mathrm{N}=86$ & Return $=9.12 \%$ \\
\hline
\end{tabular}

SOURCES: 1990-1998 and 1999-2003 data from Jarrod Johnston and Jeff Madura, "The Performance of Internet Firms Following Their Initial Public Offering," The Financial Review 37 [2002], 529, 534. 2004 data from http://premium.hoovers.com/global/ipoc/ index.xhtml?page id=10008.

In short, prior to the dotcom bubble, the number of tech and internet related firms that issued IPOs constituted approximately one-third of all IPOs. During this time period, average initial returns for internet related IPOs almost doubled the average initial returns on non-internet IPOs, perhaps a reflection of the additional risk of these relatively hard-to-value stocks. During the dotcom bubble, the number of internet IPOs increased dramatically, to more than twice the number of non-internet IPOs. The average returns of internet related IPOs almost quadrupled the average returns experienced for non-internet IPOs. Following the dotcom bubble, internet IPOs dwindled in comparison to the number issued during the bubble, while the number of non-internet IPOs increased. Internet IPO yields settled at roughly half their pre-bubble level.

\section{CONCLUSIONS}

Prior to and following the dotcom bubble, internet and non-internet IPOs can be viewed as having normal levels of returns; as defined by Ritter [1991], Reilly and Norton [2003], and Elkind et al [2001], normal returns are between $10 \%$ and $20 \%$. The initial day returns experienced during the dotcom bubble were far from normal. Can we ascribe the return to normalcy to the actions of Elliot Spitzer? Probably not, since the sanctions were not enacted until early 2003. Even by the end of 2000, however, the investigations into investment banks issuing high-yielding internet IPOs had begun, perhaps spurring other I-banks to price the securities more appropriately. Certainly, information was being revealed to market participants surrounding the misdeeds of the investment bankers, and perhaps it is a testament to the resiliency of the markets to react to this information, or as Robert Shiller states it: "Indeed it is thanks to a market's ability to respond appropriately to such factors, for a variety of investments, that well-functioning financial markets generally promote, rather than hinder, economic efficiency" [Shiller, 2000, 18].

\section{REFERENCES}

1. Aggarwal, R., L. Krigman, and K. Womack. Strategic IPO underpricing, information momentum and lockup expiration selling. Journal of Financial Economics. Vol. 66 (2002): 105-137.

2. Bartov, E., P. Mohanran, and C. Seethamraju. Valuation of Internet Stocks-An IPO Perspective. Journal of Accounting Research. (May 2002): 321-347.

3. Elkind, P., M. Gimein, J. Boorstin, and D. Burke. The Trouble with Frank. Fortune. Vol. 144, Issue 4 (September 3, 2001): 34-43.

4. Gasparino, C. The SEC and Spitzer Might Outlaw 'Spinning' of IPOs. The Wall Street Journal. (November 5, 2002): C1, C9.

5. _ _ and M. Schroeder. Pitt and Spitzer Butted Heads To Overhaul Wall Street Research. The Wall Street Journal. (October 31, 2002): A1, A15.

6. Hanley, K. and W. Wilhelm, Jr. Evidence on the strategic allocation of initial public offerings. Journal of Financial Economics. Vol. 37 (1995): 239-257. 
7. Hansen, R. Do investment banks compete in IPOs?: the advent of the '7\% plus contract. Journal of Financial Economics. Vol. 59 (2001): 313-346.

8. http://premium.hoovers.com/global/ipoc/index.xhtml?page id=10008.

9. Johnston, J. and J. Madura. The Performance of Internet Firms Following Their Initial Public Offering. The Financial Review. Vol. 37 (2002): 525-550.

10. Ljungqvist, A. and W. Wilhelm. IPO Pricing in the Dot-com Bubble. The Journal of Finance. Vol. LVIII, No. 2 (April 2003): 723-753.

11. Loughran, T. and J. Ritter. The New Issues Puzzle. The Journal of Finance. Vol. 50, Issue 1 (March 1995): 23-51.

12. Why Has IPO Underpricing Changed Over Time? Financial Management. (Autumn 2004): 5-37.

13. Marshall, B., C. Crutchley, and D. Lending. Early Internet IPOs Versus Subsequent Entrants. Journal of Economics and Finance. Vol. 28, No. 1 (Spring 2004): 104-116.

14. Opdyke, J. and R. Simon. How You Come Out In Wall Street's Deal. The Wall Street Journal. (April 29, 2003): D1-D2.

15. Reilly, Frank K. and Edgar A. Norton. Investments, $6^{\text {th }}$ ed. (Canada: Thomson, 2003).

16. Ritter, J. The Long-Run Performance of Initial Public Offerings. The Journal of Finance. Vol. XLVI, No. 1 (March 1991): 3-27.

17. Shiller, Robert J. Irrational Exuberance. (New Jersey, Princeton University Press, 2000).

18. Smith, R. IPO Spinning Comes Under Regulatory Fire. The Wall Street Journal. (April 29, 2003$)$ : C1, C9.

19. _ S. Craig, and C. Gasparino. Street Braces for Revelations In Settlement. The Wall Street Journal. (April 25, 2003): C1, C3.

20. Zuckerman, G. and S. Craig. Settlement Establishes \$387.5 Million Fund, But Check Isn’t in Mail. The Wall Street Journal. (April 29, 2003): C1, C9.

\section{NOTES}




\section{NOTES}

